\title{
The Effects of Corrective Feedback Strategies on English Majors' Writing
}

\author{
Wenling Chen ${ }^{1}$ \\ ${ }^{1}$ School of English for International Business, Guangdong University of Foreign Studies, Guangzhou, China \\ Correspondence: Wenling Chen, School of English for International Business, Guangdong University of Foreign \\ Studies, Baiyun District, Guangzhou, China. E-mail: 838332158@qq.com
}

Received: September 2, 2018 Accepted: October 7, 2018 Online Published: October 10, 2018

doi: 10.5539/elt.v11n11p55 URL: http://doi.org/10.5539/elt.v11n11p55

\begin{abstract}
The present study, through sample analysis and questionnaires, investigates the effects of different types of corrective feedback in 250 essays of the first-year English major students and the students' responses to different feedback strategies. The study shows that 1) the students can improve their writing with the help of the feedback and that different types of errors in the English majors' writing require different feedback strategies; 2) indirect feedback (coded feedback and uncoded feedback) can be mainly used, supplemented by direct correction; and 3) the English majors highly appreciate the teacher's feedback; their preference is coded feedback, followed by direct correction and uncoded feedback This study sheds light on how different feedback strategies can be used in teaching L2 English at the university level.
\end{abstract}

Keywords: corrective feedback, direct correction, indirect feedback, coded feedback, uncoded feedback, English majors' writing

\section{Introduction}

Although errors are inevitable in the language learning process, a large proportion of them in the writing may result in misunderstanding and miscommunication. To help students to write more correctly, teachers and researchers have developed different corrective feedback strategies. Corrective feedback is defined as "any reaction of the teacher which clearly transforms, disapprovingly refers to, or demands improvement of the learner utterance" (Chaudron, 1977). In recent years, an increasing number of studies have been conducted to explore its effects in L2 development.

Relevant literature shows that different scholars hold different views about corrective feedback. Some researchers, like Truscott $(1996,1999,2004,2009)$ and Lee $(2007,2008)$, argue against it. Truscott contends that giving corrective feedback to students is ineffective or even harmful in L2 writing and time spent on it is meaningless, for the reason that the teacher may be incompetent to provide proper feedback and students may pay little attention to it. Lee comes to similar conclusion on the basis of his study of secondary writing classroom in Hong Kong. He also finds that the students do not fully utilize the teacher's feedback.

Many supporters of corrective feedback, however, emphasize its effectiveness either on the immediate revision or long-term new writing. Chandler (2003) carries out a ten-week experiment to investigate whether corrective feedback can improve the students' writing and proves it to be useful with both the students' writing accuracy and fluency. Ferris (2006), based on the data from an ESL composition class in an American university, also finds that after receiving teachers' feedback students can significantly reduce their errors during one semester and that they can improve their writing in the long run as well. Hartshorn et al. (2010) collect data in one semester about 47 ESL students of advanced-low to advanced-mid level after giving them indirect feedback. Their findings show a significant higher improvement in students' writing accuracy in the treatment group than the group that only receives traditional writing instruction.

In addition to the research done by the scholars abroad, researchers in China have also provided convincing evidence for the positive effect of corrective feedback. Chen (2009) in her 16-week experiment and Zhang (2009) in her 8-week experiment both reveal a significant progress in the English writing accuracy of the Chinese university students after they get the teacher's written corrective feedback. Song (2011) investigates 118 English major students' attitudes towards the feedback by a questionnaire survey and also proves its positive role in 
teaching English writing.

With the recognition about the effectiveness of corrective feedback, some scholars have differentiated direct feedback from indirect feedback (Walz, 1982; Ferris, 2002). Direct feedback strategy, also referred to as direct correction (DC), means that the teacher clearly indicates what is incorrect and provides the correct form at the same time. In contrast, indirect feedback strategy means that the teacher only points out the errors and the students are expected to reflect on their errors and make corrections by themselves (Ferris, 2002). As to indirect feedback, distinction is further made between coded feedback (CF) and uncoded feedback (UF). When using CF, the teacher underlines or circles the error and meanwhile gives description about what type of error it is. When choosing UF, the teacher only underlines or circles the error.

However, the empirical studies done by different researchers about different types of feedback strategies yielded different, even conflicting results. Chen (2009) concludes from the data about 54 second-year university students that the students who receive direct feedback do better than those who get indirect feedback. However, Zhang (2009) finds that indirect feedback is more effective than direct feedback in her research about 45 first-year university students.

As a result, English teachers in China still feel confused about which feedback strategy is more effective. How can they give proper feedback when facing a specific group of students and a specific type of error? Should they provide the students with direct feedback or indirect feedback? Should they give different types of feedback to different types of errors?

This study aims to clarify some confusion related to the above questions by examining how English major students perceive different types of feedback and how effectively they can correct different categories of errors based on the teacher's different feedback strategies.

The research questions include: 1) Can students make correction after getting different types of feedback? 2) How can different corrective feedback strategies be used for different types of errors? 3) Which feedback strategy is most favored by the English majors?

\section{Research Design}

\subsection{Participants of the Research}

The participants of this research are the fifty first-year English majors in two classes taught by the author in the second semester of the academic year 2016-2017. Among them, thirteen are males and thirty seven are females.

In the 18-week semester, the author assigns them five writing tasks, each essay about 150 words. In all of their first essays, errors are given DC. In their second and third ones, uncoded indirect feedback is given, with the error simply underlined as a reminder. In the fourth and fifth essays, coded indirect feedback is provided, with the errors underlined and editing symbols to illustrate the error types.

After the students get the corrective feedback of each essay, they are asked to read and understand it. For the first essay, the students are to put a "?" beside the author's correction if they fail to understand any one of it. For the other four essays, they should not only understand the feedback, but are also required to correct the errors pointed out by the author. To motivate them to be serious with the correction, the author reminds them that, except for the first essay, their essay scores consist of two parts: $50 \%$ from the first draft and $50 \%$ from the modified draft. All their first drafts and revised drafts are to be put in a portfolio, which should be submitted in the 16th week (The last two weeks of the semester are for examinations).

Finally, in the 16th week, the students are invited to finish an anonymous questionnaire with six statements and one question. The students should indicate their degree of agreement with each statement, and then answer one question. The purpose of the questionnaire survey is to explore the corrective feedback from their perspectives and find out their preference of different corrective strategies.

\subsection{Data Collection}

Fifty questionnaires and the fifty portfolios are collected in the 16th week. All the 450 drafts (50 drafts of the first essay, 100 drafts of each of the other four essays) in the portfolios are classified into three groups. The first essays with DC are put in Group 1 (G1); the first and revised drafts of the second and third essays with UF are put in Group 2 (G2); the first and revised drafts of the fourth and fifth essays with CF are put in Group 3 (G3).

Next, the answers in the questionnaires are analyzed and relevant statistics are calculated and obtained. Then the "?" in G1 is identified and counted. Finally, the errors in G2 and G3 are located and categorized based on James'(2001) classification: substance error, vocabulary error, grammar error and discourse error. 
As is shown in Table 1, most of the substance errors in the students' essays are identified with spelling, word formation, capitalization and punctuation. Vocabulary errors include wrong use of article or pronoun, wrong part of speech, wrong choice of word, wrong collocation, and wordiness or repetitive use of word. Grammar errors are found with tense, agreement, voice, sentence structure, fragment and run-on sentence. Discourse errors mainly appear with incoherence between sentences or paragraphs.

Table 1. Classification of errors

\begin{tabular}{|c|c|c|}
\hline $\begin{array}{l}\text { Classification } \\
\text { of errors }\end{array}$ & Error types & Examples from students' essays (errors underlined) \\
\hline \multirow[t]{4}{*}{ Substance error } & Spelling error & $\begin{array}{l}\text { First, parents may be too busy to take care of the child, which can } \\
\text { develop the child's indepence. }\end{array}$ \\
\hline & formation & The dog is shock by her voice. \\
\hline & Capitalization error & I asked: “what's your name?" \\
\hline & Punctuation error & $\begin{array}{l}\text { "I don't want to hurt you. If I were you, I would leave here } \\
\text { quickly"she says coldly. }\end{array}$ \\
\hline \multirow[t]{6}{*}{ Vocabulary error } & Article error & I saw many students standing in front of library. \\
\hline & Part of speech error & $\begin{array}{l}\text { To summary, both E-book and paper book should be the favorite of } \\
\text { us. }\end{array}$ \\
\hline & Word choice error & $\begin{array}{l}\text { According to the interview with some classmates, we found some } \\
\text { convictive reasons. }\end{array}$ \\
\hline & Collocation error & I wonder why he could be so good in playing it. \\
\hline & Pronoun error & But on the other hand, child may be spoiled by their grandparents. \\
\hline & $\begin{array}{ll}\text { Wordiness } & \text { or } \\
\text { repetitive use of } \\
\text { word }\end{array}$ & $\begin{array}{l}\text { After a survey concerning about why many freshmen fail to persist in } \\
\text { reading extensively, I can find four reasons. }\end{array}$ \\
\hline \multirow[t]{6}{*}{ Grammar error } & Tense error & Maybe I can find a better one when I went into society. \\
\hline & Agreement error & He never lose heart; he always stay positive. \\
\hline & Voice error & $\begin{array}{l}\text { They traveled with their own cameras which used to memorize their } \\
\text { happy time. }\end{array}$ \\
\hline & $\begin{array}{l}\text { Sentence structure } \\
\text { error }\end{array}$ & $\begin{array}{l}\text { Then grandparents always spoil the children too much, this would } \\
\text { lead to children get into bad habits. }\end{array}$ \\
\hline & Fragment & $\begin{array}{l}\text { Unbelievably, he came to me and shook my hand. Because he said } \\
\text { that fans were to him what water was to fish. }\end{array}$ \\
\hline & Run-on Sentence & $\begin{array}{l}\text { Most of the freshmen were busy with the affairs of their departments } \\
\text { and so they had little time to read in English. }\end{array}$ \\
\hline Discourse error & Incoherence & $\begin{array}{l}\text { E-books are becoming more and more popular in recent years. And } \\
\text { now, let's focus on the E-books and paper books. }\end{array}$ \\
\hline
\end{tabular}

\section{Data Analysis}

\subsection{Analysis of the Data in G1}

In the fifty essays in G1, the author totally identified 223 errors and corrected them directly in the essays. After the students got the feedback, most of them did not mark "?" beside the author's corrections, which means that they can understand the DC in their essays. Altogether only four corrections are marked with "?" in four students' essays, showing their failure to comprehend them. This indicates that students' understanding of the author's DC reaches $98.2 \%$.

\subsection{Analysis of the Data in G2}

In the first drafts of the two essays in G2, errors are only underlined without any other hints. First, each type of errors in them is added up. Then their corrections in the revised drafts are examined and the number of correct improvements is counted. Finally, the accuracy rates of the corrections are calculated. (Accuracy rate $=$ Total No. of correct improvements of each type of errors / Total No. of each type of errors $\times 100 \%$ ). The result is shown in 
Table 2.

Table 2. Students' correction of each type of errors in G2

\begin{tabular}{|c|c|c|c|c|}
\hline $\begin{array}{l}\text { Classification } \\
\text { of errors }\end{array}$ & Error types & $\begin{array}{l}\text { No. of errors in } \\
\text { the first drafts }\end{array}$ & $\begin{array}{l}\text { No. of correct } \\
\text { improvements in } \\
\text { the revised drafts }\end{array}$ & $\begin{array}{l}\text { Accuracy } \\
\text { rate of } \\
\text { correction }\end{array}$ \\
\hline \multirow[t]{4}{*}{ Substance error } & Spelling error & 41 & 39 & $95.1 \%$ \\
\hline & Word formation error & 56 & 52 & $92.9 \%$ \\
\hline & Capitalization error & 37 & 33 & $89.2 \%$ \\
\hline & Punctuation error & 26 & 23 & $88.5 \%$ \\
\hline \multirow{6}{*}{$\begin{array}{l}\text { Vocabulary } \\
\text { error }\end{array}$} & Article error & 12 & 9 & $75 \%$ \\
\hline & Part of speech error & 46 & 37 & $80.4 \%$ \\
\hline & Word choice error & 25 & 10 & $40 \%$ \\
\hline & Collocation error & 28 & 16 & $57.1 \%$ \\
\hline & Pronoun error & 10 & 7 & $70 \%$ \\
\hline & Wordiness or repetitive use of word & 11 & 6 & $54.5 \%$ \\
\hline \multirow[t]{6}{*}{ Grammar error } & Tense error & 54 & 42 & $77.8 \%$ \\
\hline & Agreement error & 46 & 34 & $73.9 \%$ \\
\hline & Voice error & 4 & 3 & $75 \%$ \\
\hline & Sentence structure error & 45 & 17 & $37.8 \%$ \\
\hline & Fragment & 12 & 8 & $66.7 \%$ \\
\hline & Run-on sentences & 3 & 2 & $66.7 \%$ \\
\hline \multirow[t]{2}{*}{ Discourse error } & Incoherence between sentences & 27 & 8 & $29.6 \%$ \\
\hline & Incoherence between paragraphs & 14 & 6 & $42.9 \%$ \\
\hline Average & & & & $67.4 \%$ \\
\hline
\end{tabular}

From the statistics in Table 2, UF can help the students to eliminate $67.4 \%$ of their errors. Although no description is given about what types of errors they are, certain categories of errors are quite effectively corrected, like all types of substance errors, article errors, part of speech errors, pronoun errors, tense errors, agreement errors and voice errors, with an accuracy rate of over $70 \%$. The errors that are best tackled are spelling errors , word formation errors and capitalization errors, with the accuracy rates of $95.1 \%, 92.9 \%$ and $89.2 \%$ respectively.

Some other types of errors, however, are not so effectively improved, such as word choice errors, collocation errors, wordiness or repetitive use of word, sentence structure errors, and discourse errors. The accuracy rate of their corrections is lower than $60 \%$. Among them, only $29.6 \%$ of incoherence between sentences and $37.8 \%$ of sentence structure errors are properly corrected.

\subsection{Analysis of the Data in G3}

In the first drafts of the two essays in $\mathrm{G} 3, \mathrm{CF}$ is employed: errors are not only underlined, but also given symbols to illustrate what types of errors they are. All the first drafts and the revised drafts in this group are analyzed in a way similar to that in G2. The effects of this CF strategy are shown in Table 3.

Table 3. Students' correction of each type of errors in G3

\begin{tabular}{lllll}
\hline $\begin{array}{l}\text { Classification of } \\
\text { errors }\end{array}$ & Error types & $\begin{array}{l}\text { No. of errors } \\
\text { in the } \\
\text { drafts }\end{array}$ & $\begin{array}{l}\text { No. of correct } \\
\text { first }\end{array}$ & $\begin{array}{c}\text { Accuracy rate } \\
\text { improvements in correction } \\
\text { the revised drafts }\end{array}$ \\
\hline Substance error & Spelling error & 36 & 36 & $100 \%$ \\
& Word formation error & 35 & 32 & $91.4 \%$ \\
& Capitalization error & 27 & 26 & $96.3 \%$ \\
& Punctuation error & 14 & 12 & $85.7 \%$ \\
\hline
\end{tabular}




\begin{tabular}{lllll}
\hline Vocabulary error & Article error & 11 & 8 & $72.7 \%$ \\
& Part of speech error & 60 & 57 & $95.0 \%$ \\
& Word choice error & 21 & 11 & $52.4 \%$ \\
& Collocation error & 18 & 15 & $83.3 \%$ \\
& Pronoun error & 11 & 9 & $81.8 \%$ \\
& Wordiness or repetitive use of & 12 & 11 & $91.7 \%$ \\
& word & & \\
Grammar error & Tense error & 43 & 40 & $93.0 \%$ \\
& Agreement error & 48 & 44 & $91.7 \%$ \\
& Voice error & 2 & 2 & $100 \%$ \\
& Sentence structure error & 52 & 31 & $59.6 \%$ \\
& Fragment & 9 & 9 & $100 \%$ \\
Discourse error & Run-on sentences & Incoherence between sentences & 31 & $100 \%$ \\
& Incoherence between paragraphs & 22 & 13 & $51.6 \%$ \\
Average & & & $59.1 \%$ \\
\hline
\end{tabular}

Table 3 reveals that with the teacher's CF, the students improve most of their errors (83.6\%). It is worth noticing that all the spelling errors, voice errors, fragment errors and run-on sentences are effectively corrected. Substance errors, vocabulary errors and grammar errors seem to be easier for the students than discourse errors. All types of substance errors are quite properly improved, with an accuracy rate of over $80 \%$. Vocabulary errors, except for the word choice errors, are also quite effectively treated, with an accuracy rate of over $70 \%$. Moreover, many grammar errors are eliminated, such as tense errors, agreement errors, voice errors, fragments and run-on sentences.

But grammar errors in sentence structure are still ineffectively dealt with. The accuracy rate of their improvements is only 59.6\%. The same is also true with discourse errors: coherence problems turn out to be difficult for the students. Only $51.6 \%$ of the incoherence between sentences and $59.1 \%$ of the incoherence between paragraphs are revised.

\section{Results and Discussion}

\subsection{Results About the Feedback Strategies}

From the previous analysis, the students manage to correct most errors with indirect feedback. CF in G3 enables them to achieve a higher rate of accuracy (83.6\%) than UF in G2 (67.4\%). A significant increase in the accuracy rate can be found with collocation errors (from $57.1 \%$ to $83.3 \%$ ), wordiness and repetitive use of words (from $54.5 \%$ to $91.7 \%$ ), fragments (from $66.7 \%$ to $100 \%$ ) and run-on sentences (from $66.7 \%$ to $100 \%$ ).

However, in both G2 and G3, some errors, such as wrong choice of words, sentence structure errors and discourse errors, fail to be effectively corrected, with an accuracy rate of lower than $60 \%$. A few of the errors even get no corrections at all. Based on the analysis of all the revised drafts, the error types that are relatively difficult for the first-year English majors are listed in Table 4.

Table 4. Error types that are relatively difficult for correction

\begin{tabular}{llll}
\hline $\begin{array}{l}\text { Feedback } \\
\text { strategies }\end{array}$ & Error types & Examples of the error and feedback & $\begin{array}{l}\text { Student's } \\
\text { corrections }\end{array}$ \\
\hline UF in G2 & $\begin{array}{l}\text { 1. Wrong } \\
\text { choice } \\
\text { word }\end{array}$ & $\begin{array}{l}\text { However, this is a public secret by everyone } \\
\text { and they manage to kill me because no one } \\
\text { likes me. }\end{array}$ & Corrected as: managed \\
& $\begin{array}{l}\text { 2. Sentence } \\
\text { structure } \\
\text { error }\end{array}$ & $\begin{array}{l}\text { The child raised by grandparents doesn't have } \\
\text { such a problem, but he will complain his } \\
\text { parents about not loving him. }\end{array}$ & No correction made \\
& $\begin{array}{l}\text { 3. Discourse } \\
\text { error }\end{array}$ & $\begin{array}{l}\text { He said that he focused on the way to survive } \\
\text { the danger in his daily life. For example, you }\end{array}$ & No correction made \\
& & &
\end{tabular}


$\underline{\text { should calm down and get down first when }}$ you come across a fire.

$\mathrm{CF}$ in $\mathrm{G} 3$

1. Wrong choice word word) On the contrary, E-books provide a totally different reading style. (Wrong choice of

2. Sentence As a result, many freshmen spend less and less structure time in English reading that may make them error feel difficult to improve their English. (Sentence structure error)

3. Discourse E-books are becoming more and more popular error in recent years. And now, let's focus on the E-books and paper books. (Incoherence between sentences)
No correction made

Modified as: ...English reading, which may make them feel difficult to improve their English.

No correction made

\subsection{Discussion About the Feedback Strategies}

Statistics in Table 2, 3 and 4 show that the three corrective feedback strategies under discussion have their respective advantages, which means they can be used for different types of errors. Generally speaking, CF can help the students identify and correct the errors more easily than UF. But these two strategies do not make much difference with substance errors, article errors, part of speech errors, pronoun errors, tense errors, agreement errors and voice errors. Thus, these errors can be given UF to save the teacher's time for feedback. As to word choice errors, sentence structure errors and discourse errors, DC can be a better strategy, for such errors are ineffectively improved in either G2 or G3. Therefore, a combination of feedback strategies is recommended for the teachers teaching English majors at the beginners' level. The strategy to be used with each type of errors is suggested in Table 5.

Table 5. Corrective strategy recommended for each error type

\begin{tabular}{|c|c|c|}
\hline \multicolumn{2}{|c|}{ Corrective feedback strategies } & \multirow{2}{*}{$\begin{array}{l}\text { Error types } \\
\text { Spelling error }\end{array}$} \\
\hline \multirow[t]{14}{*}{ Indirect feedback strategy } & UF & \\
\hline & & Word formation error \\
\hline & & Capitalization error \\
\hline & & Punctuation error \\
\hline & & Article error \\
\hline & & Part of speech error \\
\hline & & Pronoun error \\
\hline & & Tense error \\
\hline & & Agreement error \\
\hline & & Voice error \\
\hline & $\mathrm{CF}$ & Collocation error \\
\hline & & Wordiness and repetitive use of word \\
\hline & & fragment \\
\hline & & Run-on sentence \\
\hline \multirow[t]{4}{*}{ Direct feedback strategy } & $\mathrm{DC}$ & Choice of word error \\
\hline & & Sentence structure error \\
\hline & & Incoherence between sentences \\
\hline & & Incoherence between paragraphs \\
\hline
\end{tabular}

As is shown in Table 5, indirect feedback strategy can be mainly employed for the first-year English majors' writing. Ferris et al. (2001) reveal in his research that indirect feedback can help the students correct $75 \%$ of their errors. The present study also finds $67.4 \%$ of the errors are effectively handled with UF and $83.6 \%$ with CF. In short, these two indirect feedback strategies can help students deal with most of their errors, thereby improving 
their writing.

Indirect feedback is better than DC in that it can engage learners in "guided learning and problem solving" (Lalande, 1982). It can raise students' awareness of the errors, identify and correct them, and finally develop the students' ability to correct their own errors (Chandler, 2003; Ferris et al., 2001; Robb et al., 1986; Yates et al., 2002). This can eventually lead to students' long-term progress. After all, too much DC may result in students' reliance on the teacher and their passive attitude towards feedback.

Although the effectiveness of indirect feedback has been confirmed by this study and other scholars (Bitchener et al., 2005; Chandler, 2003; Ferris et al., 2001), this study also finds that it cannot completely replace DC. For some errors, first-year English majors still have trouble figuring them out even if the errors have been pointed out. That is, they know the error, but they do not know why it is wrong or how it can be corrected. Take the choice of word error as an example. First-year students' failure to correct them may result from their limited vocabulary or their inability to distinguish between synonyms. Without the teacher's further help, the students' problems may remain unsolved.

DC, therefore, is useful for such errors. This strategy can prompt the students to compare their wrong language with the teacher's correct expression so that they can notice the gap between their interlanguage and the correct target language. According to Schmidt's Noticing Hypothesis, not all input is of the same value; input cannot become intake for language learning unless it is noticed (Schmidt, 1990). The students' consciousness of their own linguistic errors can lead them to attend to the teacher's correct input, which can benefit their language learning. Thus, when the teacher can foresee the student's difficulty with certain types of errors, DC can be a better choice. Anyway, DC can be more easily comprehended with complicated errors, which is confirmed by the fact that $98.2 \%$ of them can be understood in G1 of the students' essays.

In conclusion, different types of errors require different feedback strategies. DC is recommended only when necessary, for it is time and energy consuming for teachers and too frequent use of it may weaken students' motivation to improve their own writing. Teachers can flexibly use UF or CF for most errors to enhance students' positive learning attitude and increase the working efficiency as well.

\subsection{Results About the Students' Response to the Feedback}

The students' response to the feedback strategies is investigated in the questionnaire. Their indication of agreement with each statement in the survey is noted down and the result is presented in Table 6.

Table 6. Students' response to the corrective feedback strategy

\begin{tabular}{|c|c|c|c|c|c|}
\hline \multirow[t]{2}{*}{ Statements } & \multicolumn{5}{|c|}{ Degree of Agreement } \\
\hline & $\begin{array}{l}\text { 1.Strongly } \\
\text { disagree }\end{array}$ & 2.Disagree & $\begin{array}{l}\text { 3. Neither } \\
\text { agree nor } \\
\text { disagree }\end{array}$ & 4. Agree & $\begin{array}{l}\text { 5. Strongly } \\
\text { agree }\end{array}$ \\
\hline $\begin{array}{l}\text { 1. It is necessary for the teacher to give } \\
\text { corrective feedback to my writing. }\end{array}$ & $0 \%$ & $2 \%$ & $2 \%$ & $24 \%$ & $72 \%$ \\
\hline $\begin{array}{l}\text { 2. I read the teacher's feedback in my } \\
\text { essays carefully. }\end{array}$ & $0 \%$ & $2 \%$ & $12 \%$ & $64 \%$ & $22 \%$ \\
\hline $\begin{array}{l}\text { 3. When I meet difficulties with my error } \\
\text { correction, I often consult } \\
\text { dictionaries or reference books, surf } \\
\text { online, or discuss with my } \\
\text { classmates. }\end{array}$ & $4 \%$ & $8 \%$ & $6 \%$ & $68 \%$ & $14 \%$ \\
\hline $\begin{array}{l}\text { 4. The teacher's direct correction in } \\
\text { Essay } 1 \text { is helpful. }\end{array}$ & $0 \%$ & $2 \%$ & $6 \%$ & $14 \%$ & $78 \%$ \\
\hline $\begin{array}{l}\text { 5. The teacher's uncoded feedback in } \\
\text { Essay } 2 \text { and } 3 \text { is helpful. }\end{array}$ & $2 \%$ & $14 \%$ & $14 \%$ & $46 \%$ & $24 \%$ \\
\hline $\begin{array}{l}\text { 6. The teacher's coded feedback in Essay } \\
4 \text { and } 5 \text { is helpful. }\end{array}$ & $2 \%$ & $2 \%$ & $10 \%$ & $26 \%$ & $60 \%$ \\
\hline
\end{tabular}


In Table 6, the answers "Strongly disagree" and "Disagree" are analyzed as negative, while "Strongly agree" and "Agree" are interpreted as positive.

The statistics show that $96 \%$ respondents give positive answers to the first statement about the necessity of the teacher's written feedback. In the second statement, $86 \%$ of them strongly agree or agree that they carefully read the teacher's feedback to their five essays.

The answers to Statement 3 reveal that $82 \%$ of the respondents often consult dictionaries or reference books, surf online, or discuss with their classmates when confronted with difficulties in their error correction.

Besides, most of them react to Statement 4, 5 and 6 positively. The most helpful feedback strategy to them is DC in Essay 1, with $92 \%$ of the students giving positive answers. Next is CF in Essay 4 and 5, with $86 \%$ positive answers. UF in Essay 2 and 3 is also considered helpful by $70 \%$ of the students. DC and CF are considered more helpful than UF.

In addition to the respondents' opinions about the statements, their answers to the last question about their preference of the three different corrective strategies are shown in Chart 1.

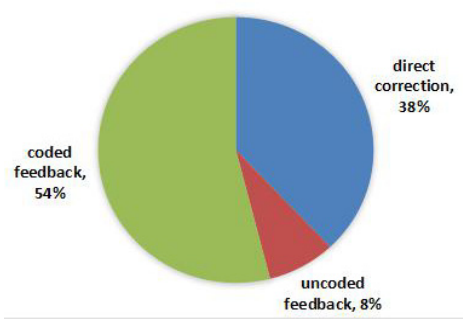

Chart 1. Students' preference of the corrective strategies

Chart 1 reveals that the students' favorite corrective strategy out of the three under discussion is CF (54\%), followed by DC (38\%) and UF ( $8 \%)$.

\subsection{Discussion About the Students' Response to the Feedback}

The survey results indicate that the vast majority of the respondents react positively to the teacher's corrective feedback. This is understandable. As is pointed out by Song (2011), language accuracy is a very common concern of English learners in China, who expect their teachers to help them locate every error, especially grammar errors, so as to improve their writing skill and English proficiency. Such expectations of the students are also recognized by Leki (1991), Schultz (1996) and Hyland (2003) in their research about language learners in other countries. The students' positive attitude determines the effect of the teacher's feedback to a great extent, for they should process the feedback so as to acquire the knowledge that they can apply to their future writing.

It is also found that many respondents can try to solve the problems by themselves when they meet difficulties in their essay revision. This means indirect error feedback can help to develop the students' independent learning ability in this correction process.

From most students' perspective, both DC and indirect feedback help them to realize their errors and then to correct them. But a higher percentage of approval can be found with DC and CF than UF. This result is similar to that in Ferris' research (Ferris et al., 2001). DC is considered the most helpful, probably because it is the fastest way for the students to reduce the confusion and the easiest way to internalize the correct target forms (Chandler, 2003). CF is also useful for them, mainly because it specifies the error type, enabling the students' to be more efficient in improving their errors than UF.

Surprisingly, CF turns out to be the students' most preferred strategy although they consider DC to be the most helpful. One possible reason is that with proper hints, English majors at the beginners' level are competent enough to cope with most of their errors quite efficiently and accurately. Many of them, therefore, do not expect so much DC from the teacher.

UF is the least popular, probably because UF without any hints about how to correct the errors may lead to the students' uncertainty and confusion about their own corrections even after they make the improvements according to the UF. This reminds teachers that when using this strategy, they had better give further feedback after reading and scoring the students' modified drafts. The students may need timely confirmation about whether their corrections are right or not. 


\section{Conclusion}

The study reveals that the first-year English majors can understand most of the teacher's feedback and correct most of the errors. CF leads to a higher accuracy rate in the correction than UF, especially for such error types as collocation errors, wordiness and repetitive use of words, fragments and run-on sentences. Nevertheless, with CF and UF, a large percentage of word choice errors, sentence structure errors and discourse errors remain uncorrected. DC tends to be more effective for these types of errors.

Thus, if the teachers employ process-teaching method and require the student to submit a revised draft after giving the feedback, they are suggested to use a combination of feedback strategies: DC for the errors in the choice of word, sentence structure and coherence; $\mathrm{CF}$ for the errors with collocation, wordiness, fragment and run-on sentence; and UF for substance errors and errors in tense, agreement and voice.

Besides, the survey finds that the English majors react actively to the teacher's feedback and appreciate the feedback highly; their preference is CF, followed by DC and UF. Taking this into account, the teachers who do not want to differentiate among different feedback strategies can just use CF consistently in one essay, for its effects on most types of errors are proved to be good. It is also practical because it is more time-efficient and less laborious than DC.

However, there are still some limitations in this study. Firstly, the student participants come from the same university, which may affect the generalizability of the results. Secondly, though the author sometimes discusses with her colleagues from the English-speaking countries, the identification and classification of errors largely depends on her own understanding, which may be incomplete or inaccurate in some cases. Thirdly, the long-term effect of corrective feedback on the students' new writing has not been studied. As a result, this research sheds little light on how corrective feedback benefits the English majors' writing in the long run.

Given the above limitations, future research can try to analyze more samples from different universities. Researchers can also track students' long-term progress in their English writing, finding out whether the students given a combination of corrective feedback strategies can outperform those given just a certain type of feedback.

\section{References}

Bitchener, J., \& U. Knoch. (2008). The value of written corrective feedback for migrant and international students. Language Teaching Research, 12, 409-431. https://doi.org/10.1177/1362168808089924

Bitchener, J. et al. (2005). The effect of different types of corrective feedback on ESL student writing. Journal of Second Language Writing, 14, 191-205. https://doi.org/10.1016/j.jslw.2005.08.001

Chandler, J. (2003). The efficacy of various kinds of error feedback for improvement in the accuracy and fluency of L2 student writing. Journal of Second Language Writing, 12(3), 267-296. https://doi.org/10.1016/S10603743(03)00038-9

Chaudron, C. (1977). A descriptive model of discourse in the corrective treatment of learners' errors. Language Learning, 27, 29-46. https://doi.org/10.1111/j.1467-1770.1977.tb00290.x

Chen, X. X., \& Li, H. N., (2009). The effect of teacher's written corrective feedback on English writing. Foreign Language Teaching and Research, 5, 351-358.

Ferris, D. (1999). The case for grammar correction in L2 writing classes: A response to Truscott. Journal of Second Language Writing, 8(1), 1-11. https://doi.org/10.1016/S1060-3743(99)80110-6

Ferris, D. (2002). Treatment of error in second language student writing. Ann Arbor: University of Michigan Press.

Ferris D. (2006). Does error feedback help student writers? New evidence on the short- and long-term effects of written error correction. In K. Hyland, \& F. Hyland (Eds.), Feedback in second language writing: Contexts and issues. New York, NY: Cambridge University Press. https://doi.org/10.1017/CBO9781139524742.007

Ferris, D. (2001). Error feedback in L2 writing classes: How explicit does it need to be? Journal of Second Language Writing, 10(3), 161-184. https://doi.org/10.1016/S1060-3743(01)00039-X

Hartshorn, K. J. (2010). Effects of dynamic corrective feedback on ESL writing accuracy? TESOL Quarterly, 44, 84-109. https://doi.org/10.5054/tq.2010.213781

Hyland, F. (2003). Focus on form: Student engagement with teacher feedback. System, 31(2), 217-230. https://doi.org/10.1016/S0346-251X(03)00021-6

James, C. (2001). Errors in language learning and use: Exploring error analysis. Beijing: Foreign Language 
Teaching and Research Press.

Lalande, J. R. (1982). Reducing composition errors: An experiment. Modern Language Journal, 66(2), 140-149. https://doi.org/10.1111/j.1540-4781.1982.tb06973.x

Lee, I. (2007). Feedback in Hong Kong secondary writing classroom: Assessment for learning or assessment of learning? Assessing Writing, 12, 180-198. https://doi.org/10.1016/j.asw.2008.02.003

Lee, I. (2008). Student reactions to teacher feedback in two Hong Kong secondary classrooms. Journal of Second Language Writing, 17(3), 144-164. https://doi.org/10.1016/j.jslw.2007.12.001

Leki, I. (1991). The preference of ESL students for error correction in college-level writing class. Foreign Language Annals, 24(3), 203-218. https://doi.org/10.1111/j.1944-9720.1991.tb00464.x

Robb, T., et al. (1986). Salience of feedback on errors and its effect on EFL writing quality. TESOL Quarterly, 20(1), 83-93. https://doi.org/10.2307/3586390

Schmidt, R. (1990). The role of consciousness in second language learning. Applied Linguistics, 11, 206-226. https://doi.org/10.1093/applin/11.2.129

Schultz, R. (1996). Focus on form in the foreign classroom: Students and teachers views on error correction and the role of grammar. Foreign Language Annals, 29(3), 343-364. https://doi.org/10.1111/j.1944-9720. 1996.tb01247.x

Song, T.H., (2011). Research on the corrective feedback in teaching EFL writing. Journal of Xi'an International Studies University, (4), 67-69.

Truscott J. (1996). The case against grammar correction in L2 writing classes. Language Learning, 46, 327-369. https://doi.org/10.1111/j.1467-1770.1996.tb01238.x

Truscott, J. (1999). The case for "the case against grammar correction in L2 writing classes": A response to Ferris. Journal of Second Language Writing, 8, 111-122. https://doi.org/10.1016/S1060-3743(99)80124-6

Truscott, J. (2004). Evidence and conjecture on the effects of correction: A response to Chandler. Journal of Second Language Writing, 13, 337-343. https://doi.org/10.1016/j.jslw.2004.05.002

Truscott, J. (2009). Arguments and appearances: A response to Chandler. Journal of Second Language Writing, 18, 59-60. https://doi.org/10.1016/j.jslw.2008.09.001

Walz, J. (1982). Error correction techniques for the Fl classroom. Washington D.C.: The Center for Applied Linguistics and Harcourt Brace Jovanovich, Inc.

Yates, B. (2002). Responding to sentence-level errors in writing. Journal of Second Language Writing, 11(1), 29-47. https://doi.org/10.1016/S1060-3743(02)00051-6

Zhang, W., \& Deng, Y. P. (2009). Effect of corrective feedback on the writing level of university students. Foreign Language and Literature, 6, 139-144.

\section{Copyrights}

Copyright for this article is retained by the author(s), with first publication rights granted to the journal.

This is an open-access article distributed under the terms and conditions of the Creative Commons Attribution license (http://creativecommons.org/licenses/by/4.0/). 